\title{
AUS, AGA SIIRAS
}

Kihnu pulma protokoll näeb ette järgmist:

4.7. Pruuti ehitakse.

4.8. Pruut tantsib.

4.9. Pruut häbeneb.

See meenub mulle alati, kui kuulen räägitavat eesti kirjanduses maadvõtvast „uussiirusest” või „uusaususest”. Aja Käsk on olla siiras ja aus. „Nüüd on taas lubatud lihtsus ja naiivsus. [---] Naeruväärsus laotab end häbenemata naermiseks välja. See kõik on vaatamata oma võimalikule teesklusefaktorile [?] siiski endisest ausam."1 Mis värk see on? Väljamaa värk, importkaup new sincerity. „Irony was dead... It was to be replaced by soft, sweet sincerity," kuulutab uussiiruse manifest. ${ }^{2}$

Sama jõulisi deklaratsioone on nüüd ilmunud meiegi pressis: „Postmodernism rääkis teiste sõnadega, uussiirus räägib oma sõnadega. Postmodernism kasutab teoste ülesehitamisel eri materjale, kombineerides iidset kiviseina kipsplaadiga; uussiirus ehitab kõik seinad läbipaistvast klaasist. Postmodernism avab uksed valitutele, uussiirus puistab südant võorale."3 Süvatasandil on ausus ja siirus kunstilise eneseväljenduse enesestmõistetav eeldus, olgu väljendusvahendid millised tahes. Milleks seda eraldi deklareerida?

Nagu näha, vastandab uussiirus end postmodernismile. Kuid postmoder-

${ }^{1} \mathrm{~K}$. Prints, Metanaer uussiiruse üle. Eesti Ekspress 2. VI 2011.

2 http://www.maximumfun.org/blog/2006/ 02/manifesto-for-new-sincerity.html.

${ }^{3}$ I. Kotju h, Kirjandus, mis räägib oma sõnadega. - Eesti Ekspress 2. VI 2011. nism pole jätnud eesti kirjandusse kuigi palju jälgi. Postmodernistlikeks võib ehk pidada küpse Mati Undi romaane, eriti tema hiliseid dramatiseeringuid, nii et kogu nähtus taandub suurelt jaolt ühe geeniuse isikupärasele vaimulaadile. Hea tahtmise korral leiab postmodernismi jooni ka Jüri Ehlvesti ja Hasso Krulli 1990. aastate loomingust. Aga see on ka enam-vähem kõik. Tagantjärele on teoreetikudki tunnistanud, et kuulutused postmodernismi valitsemisest läinud kümnendite eesti kirjanduses olid kõvasti üle pingutatud. Nii resümeerib Aare Pilv: „Postmodernsuse mõistel pole minu jaoks kunagi väga suurt heuristilist jõudu olnud (kui, siis mõnevõrra poliitilis-ühiskondliku diskursi kirjeldamisel, kuid mitte kultuuri ja kunsti puhul)...." Jaak Tomberg lisab: „Nii nagu tühja tähistajagagi, on seda mõistet kasutatud liiga palju, et ta enam midagi tähendaks; see mõiste osutab liiga paljudele asjadele (ehk ainuüksi olemasoleva pelgale totaalsusele), et suuta enam kirjeldada midagi konkreetset...."4

Ka uussiiruse retseptsioonis valitseb suur segadus. Selle musternäiteks on peetud Andrus Kasemaad, aga sama sildiga on märgistatud kirjasõnas ka Kristiina Ehinit, Siim Nurklikku, Tõnu Õnnepalu, Hasso Krulli, Elo Viidingut, Mari Tarandit ja isegi räigevõitu Mihkel Rauda ning sarkastilist fs-i. Mis võiks olla neil ühist? Kõige tipuks on siiruses

${ }^{4}$ A. Pilv, Kirjake provintsist. - Vikerkaar 2011, nr 4-5, lk 158; J. To m b e r g, „Praeguste” peadpööritav taastulek. Postmodernismi mõiste nüüdisaegsest funktsiooni(tuse)st. - Vikerkaar 2011, nr 4-5, lk 160. 
kahtlustatud ka Sven Kivisildnikku, meie ainsat järjekindlat dekonstruktivisti, kes sattus sellele soonele veel enne, kui kuuldused uuest menetlusest Eestimaale jõudsid. Mingiks koolkonnaks loetletud isikud küll ei koondu.

Kuigi postmodernism meil jalgu alla ei saanud, kujunes sajandivahetusel vähemalt luules välja üks üsna kindel kaanon - või peaks ütlema: diskursus -, ühiskonnakriitiline kibestunud vabavärss, mida viljelesid näiteks Elo Vee ja fs. Tõstes nüüd kilbile siiruse, kvalifitseerime selle hoiaku tahes-tahtmata poosiks. Vahest on selles omajagu tõtt. Nendes sappi pritsivates või elutüdimust väljendavates tekstides oli palju epateerimist ja noorusele kohustuslikku negativismi. Aga mootor muudkui töötab ja töötab, meetod on leidnud kuni viimase ajani hulgaliselt järgijaid (Triin Tasuja, Tuuli Taul jt), kuigi ilmutas juba ammu kulumise märke. Uued tulijad mõistsid, et samas vaimus enam jätkata ei saa, ja pidid võtma teistsuguse hoiaku.

Olen nõus Märt Väljatagaga, kui ta kirjutab: „Vastuvõtja mäluulatuse lühenedes piisab lõppude lõpuks kultuuri arenguks ainult kahest faasist, mis üksteist regulaarselt üha kiiremini välja vahetavad: nt iroonia ja siirus, keerulisus ja lihtsus jne. Tuleb ainult silmas pidada õiget aega, millal mõnele püsielemendile ette kleepida liide "uus" ". ${ }^{5}$ See on kultuuri fülogeneetiline plaan. Uus sugupõlv vastandab end järsult kujunenud kaanonile.

Tõsi on see, et viimastel aastatel on luules midagi muutunud. Muutunud on hoiakud ja temaatika. Poeetika, tehniline võttestik ja kujundisüsteem on jäänud üldjoontes samaks. Praegune noor luule on loobunud sõjakusest, on eelnevaga võrreldes märksa soojem ja intiimsem. Ilmselt ei tulene see mingi doktriini järgimisest, vaid on igati loo-

${ }^{5}$ M. Väljat a ga, Mõtleme veel. - Vikerkaar 2011, nr 4-5, lk 166. mulik reaktsioon. Kirjandusel on oma sisemine arenguloogika.

Kõrvalepõike korras olgu öeldud, et ka ontogeneetilises plaanis on sellised järsud pöörded küllaltki tavalised, kuid nad on enamasti ühesuunalised: artistlikkusest loobutakse lihtsuse, rollimängudest avaluse ja eheduse kasuks. Tuletagem meelde kas või Debora Vaarandi lahtiütlemist õonsast paraadluulest ning tagasipöördumist „lihtsate asjade juurde" ja mängurist Jüri Üdi ümbersündi tõekuulutajaks Juhan Viidinguks.

Suhtudes skeptiliselt moevooludesse, ei jutlusta ma isolatsionismi. Me oleme integreerunud Euroopaga majanduslikult ja peame seda olema ka vaimselt, umbes samal kombel, nagu sageduse hoidmiseks tuleb olla ühenduses mingi suurema regiooni elektrivõrguga. (See on nüüd küll õnnetu analoogia: kuigi loome lääne suunal uusi ühendusi, ei saa me siiani ennast Venemaast lahti haakida.)

Kõik lääne vaimuvoolud ja mentaalsed rõhkkonnad jõuavad üsna pea ka meie maale. Nii on olnud vähemalt Noor-Eestist alates ja on seda kindlamalt praeguses võrgustunud Eestis. Pealegi sõeluvad luuletajad nüüd pidevalt festivalide vahet. Sellegipoolest, nagu on öelnud W. H. Auden: „Paabeli needuse tõttu on luule kõikidest kunstidest kõige provintslikum, aga tänapäeval, kui tsivilisatsioon on üle kogu maailma üksluiselt ühetaoliseks muutumas, võib seda pidada pigem õnnistuseks kui needuseks: vähemalt luules ei saa tekkida „internatsionaalset stiili”.”6 Siinne siirusepuhang on ilmselt isetekkeline, vastukaal ammenduvale sarkastilisele liinile, Läänest on laenatud üksnes manifest. Ja üleüldse usun ma, et vaimuimpordis ja uute paradigmade kehtestamisel ei ole määrav roll mitte kirjanikel, vaid kirjandusteadlastel.

${ }_{6}$ W. H. A u d e n, Kirjutamine. - W. H. Auden, 39 luuletust ja 5 esseed. Loomingu Raamatukogu 2012, nr 3-6, lk 80. 
Sest nad on sundseisus. Kui mõni mõttesuund metropolides kuulsust kogub, peavad nad kohe ennast vastavale lainele häälestama. Nad peavad olema moodsad ja rahvusvahelised. Et pääseda Teadusfondi (nüüdse Teadusagentuuri) katla äärde, tuleb osaleda rahvusvahelistes projektides, esineda ülemaailmsetel konverentsidel, anda endast märku ingliskeelses kultuuriruumis, ühesõnaga, tuleb laulda sama laulu mis kolleegid tähtsamates keskustes. Ja kui mõni Läänes tähelepanu keskmesse sattunud fenomen meie kirjanduses puudub, siis ei jää üle muud, kui see konstrueerida.

JOEL SANG 